\title{
The synthesis of biodiesel catalyzed by Mucor miehei lipase immobilized onto aminated polyethersulfone membranes
}

\author{
Nurrahmi Handayani ', Deana Wahyuningrum, Muhammad Ali Zulfikar, Santi Nurbaiti, Cynthia L. Radiman \\ and Buchari
}

\begin{abstract}
Background: Nowadays, biodiesel has become more attractive in the quest for a novel fuel source due to its environmental benefits and the biodegradable properties. Transesterification of Helianthus annuus (sunflower) seeds oil is one of methodsacci for producing biodiesel fuel. However, during this process, the impurities are frequently found in the synthesized biodiesel which degrades the quality of biodiesel. Therefore, a proper catalyst is required to obtain the high-quality biodiesel. In this study, a series of aminated polyethersulfone (PES-NH 2 ) membranes was prepared as solid support for immobilized Mucor miehei lipase. Glutaraldehyde was used as a cross-linker agent in immobilization process to investigate the effect of spacer toward biodiesel production.
\end{abstract}

Results: Based on elemental analysis, lipase was successfully attached onto PES-NH 2 membranes and formed physical interactions. Enzyme loading values of synthesized membrane were higher than that of commercial filtration membrane. LC-MS analysis with C18 as a column showed that butyl palmitate, butyl linoleate, and butyl oleate were produced from transesterification reaction of triglyceride from sunflower oil and butanol. Based on FTIR analysis, the imine group as a covalent bond was successfully obtained during the cross-linking reaction. After reaction with the spacer, the enzyme loading was increased significantly from 177.05 to $911.48 \mu \mathrm{g} / \mathrm{cm}^{2}$. The alkyl esters produced also showed high values after the cross-linking. According to biodiesel quality tests, the results were matched with the values specified by the ASTM.

Conclusion: Biodiesel from sunflower seeds oil was successfully synthesized through a transesterification reaction catalyzed by Mucor miehei lipase immobilized onto the synthesized aminated PES membrane. The addition of glutaraldehyde as a cross-linker showed an excellent enzyme loading value and led to significantly increased biodiesel conversion efficiency. This method is good to be developed, since the immobilized enzyme stability could be increased, the separation process was easier, and a high yield with good quality of biodiesel could be obtained.

Keywords: Helianthus annuus, Sunflower seeds oil, Biodiesel production, Aminated polyethersulfone membranes, Immobilized enzyme, Mucor miehei lipase, Glutaraldehyde

\section{Background}

Biodiesel is an alternative fuel for diesel engines derived from vegetable oils or animal fats and composed of fatty acid alkyl esters (FAAE) (Moser 2009). Some attractive properties of biodiesel, such as low toxicity, derivation

*Correspondence: nurrahmi.105@gmail.com

Department of Chemistry, Institut Teknologi Bandung, Jalan Ganesha 10, Bandung, Indonesia

Springer Open from a renewable resource, free of sulfur and aromatic compounds, flash point, and biodegradability are the reasons why research on biodiesel is still popular today (Ma and Hanna 1999). Transesterification is a process of converting the oils or fats into biodiesel fuel by removing the glycerin and creating an alcohol ester. In the end of reaction, glycerin is left on the bottom and alcohol ester is left on the top (Demirbas 2002). The major problem during this process is the impurities often found in the 
synthesized biodiesel which contributes to the physical properties of biodiesel. Therefore, a proper catalyst is needed to obtain the high-quality biodiesel. A good biodiesel quality should at least meet the standard of American Society for Testing Materials (ASTM) as listed in Table 1.

Lipase is one of the biocatalysts widely used in the synthesis of biodiesel due to several advantages such as allowing for synthesis of specific alkyl esters, having a low toxicity and biodegradable property, and capable of working on mild condition (Nelson et al. 1996). In order to optimize the biodiesel production, some drawbacks of lipase in terms of product recovery, stability, and reusability properties can be resolved by immobilization of enzyme (Hilal et al. 2006; Tan et al. 2010). However, the design of an efficient lipase immobilized system is still a complicated task. It does not only depend on the particular lipase type, but also the type of reaction system (organic solvent, aqueous condition, or organic-aqueous interface), the condition of process (temperature, pressure, $\mathrm{pH}$ ), and the time of reaction (Balcao et al. 1996).

The immobilization of enzymes onto macroporous beads was accomplished through physical interaction or chemical bonding between the enzymes and the active groups existing on the surface of solid support (Soares et al. 2003; Miletic et al. 2009). Some publications also reported that the enzymes were successfully attached onto a polymer or membrane (Arica and Hasirci 1987; Eldin et al. 2000; Kobayashi et al. 2006). Studies in the immobilization methods and the appropriate solid support will continue to grow due to the attractive properties of immobilized enzyme and their vast range of functions.

The present work focuses on the investigation a biocatalytic membrane reactor that can improve the enzymes performance as well as a filter which is able to separate the biodiesel from its by-product (Giorno and Drioli 2000). By some methods of characterization, the properties of biodiesel produced by the immobilized enzyme are also investigated. The support material used in this study is aminated polyethersulfone $\left(\mathrm{PES}-\mathrm{NH}_{2}\right)$ which

Table 1 Standard of several biodiesel properties specified by ASTM

\begin{tabular}{llll}
\hline Characteristics & Methods & Limit & Unit \\
\hline Flash point & ASTM D93 & $\begin{array}{c}52.8 \pm 2.3 \text { to } \\
133.9 \pm 5.9\end{array}$ & ${ }^{\circ} \mathrm{C}$ \\
& & $18(\max )$ & ${ }^{\circ} \mathrm{C}$ \\
Cloud point & ASTM D2500 & -57 to +51 & ${ }^{\circ} \mathrm{C}$ \\
Pour point & ASTM D5949 & $115(\max )$ & $\%(\mathrm{~g} / 100 \mathrm{~g})$ \\
lodine value & ASTM D1959 & $1.9-6.0$ & $\mathrm{~mm} / \mathrm{s}$ \\
$\begin{array}{l}\text { Kinematic viscosity } \\
\left(40{ }^{\circ} \mathrm{C}\right)\end{array}$ & ASTM D445 & & $\mathrm{kg} / \mathrm{m}^{3}$ \\
\begin{tabular}{l} 
Density $\left(40{ }^{\circ} \mathrm{C}\right)$ \\
\hline
\end{tabular} & ASTM D1298 & $850-890$ & \\
\hline
\end{tabular}

had been previously synthesized and reported by the authors (Handayani et al. 2012). From the previous work, although the enzyme interacted with $\mathrm{PES}-\mathrm{NH}_{2}$ membranes through physical interaction, the enzyme activity was not decreased during the immobilization. On this research, optimizations of enzyme interaction are performed using a cross-linker. Glutaraldehyde as a crosslinker agent has a role in making such a bridge between the enzymes with the solid support by covalent linkage (Handayani et al. 2011). Through a series of tests, this study investigates the effect of cross-linker addition toward the enzyme stability and the produced biodiesel.

\section{Methods}

\section{Materials and tools}

The synthesized PES- $\mathrm{NH}_{2}$ membranes were prepared as described in the previous study (Handayani et al. 2012). $N$-methyl pyrrolidone (NMP) was supplied by Across Organics. Dibutyl phthalate (DBP), polyethylene glycol (PEG), glutaraldehyde, $n$-hexane, and Mucor miehei lipase in the form of brownish powder were purchased from Sigma-Aldrich. Methanol was of analytical grade and purchased from Lab-Scan Analytical Sciences. All the chemicals were of analytical grade and used without further purification. Bicinchoninic acid (BCA) protein assay apparatus was supplied by Thermo Scientific. Sunflower seeds oil was obtained from the local market.

Fourier transform infrared (FTIR) and IR spectra of the polymers were obtained by JASCO FT/IR-5000 spectrophotometer and Buck Scientific Model M-500 IR spectrophotometer, respectively. UV/VIS measurements were carried out on a PYE UNICAM SP8-200 UV/VIS and GENESYS 20 UV/VIS spectrophotometer. Surface area and porosity of the membranes were determined by QUANTACHROME autosorb iQ Model ASIQM0000-3. LC-MS Mariner Biospectrometry was used for the identification of transesterification products.

\section{Membrane's preparation}

PES was synthesized by condensation polymerization which followed Keitoku's procedure with several modifications as described in the previous work (Keitoku et al. 1994; Handayani 2010; Handayani et al. 2012). Aminated PES (PES- $\mathrm{NH}_{2}$ ) was obtained by a nitration reaction of synthesized PES and followed by a reduction reaction using $\mathrm{SnCl}_{2} \cdot 2 \mathrm{H}_{2} \mathrm{O}$. PES and PES- $\mathrm{NH}_{2}$ membranes with certain composition of additives were obtained by inversion phase technique. To the homogenous polymer solution in NMP, PEG as pore-size controller and DBP as plasticizer were added and mixed by stirring at $200 \mathrm{rpm}$ and room temperature for $24 \mathrm{~h}$. The casting solution was poured on a glass plate and immediately immersed into a distilled water coagulation bath at room temperature for 
immersion precipitation. The obtained membrane was kept for $1 \mathrm{~h}$ until the residual solvent was totally removed. Finally, the membrane was dried for $24 \mathrm{~h}$ at room temperature and characterized by SEM. The same procedure was performed on each casting solution which has been prepared with the composition as shown in Table 2.

\section{Immobilization of lipase}

Membranes with certain composition of polymer, DBP, and PEG as shown in Table 2 with a thickness of 0.045$0.05 \mathrm{~mm}$ and diameter of $4.7 \mathrm{~cm}$ were mixed with $5 \mathrm{~mL}$ of Mucor miehei lipase solution $(2 \mathrm{mg} / \mathrm{mL})$ in a PBS buffer $(\mathrm{pH} 7)$. The samples were incubated in a rotary shaker with velocity of $200 \mathrm{rpm}$ at $30^{\circ} \mathrm{C}$ for $24 \mathrm{~h}$. Separation of the immobilized lipase and the supernatant was carried out by decantation. The membranes with immobilized lipases were washed with PBS buffer and distilled water, until no enzymes were detected in the solution. The supernatants and washing solutions were used for enzyme loading determination. The tests were carried out by a Lowry method for determination of the amount of attached enzyme using UV/VIS spectrophotometer. The lipases immobilized onto the membranes were dried by liquid nitrogen and stored in a vacuum oven for $24 \mathrm{~h}$ at room temperature.

\section{The synthesis of biodiesel using immobilized lipase as a catalyst}

The synthesis of biodiesel was performed by transesterification reaction using a membrane bioreactor (MBR). A $250 \mathrm{~mL}$ membrane reactor system was constructed as shown in Fig. 1. PESNH 2 -10 D5 P8 membrane with the presence of immobilized lipase and diameter of $47 \mathrm{~mm}$ was inserted in the membrane cell of the reactor. To the $25 \mathrm{~g}$ of sunflower oil, $150 \mathrm{mmol}$ of $n$-butanol was added. The selection of the type of alcohol was carried out based on the simplicity to form biodiesel with liquid form in the room temperature (Ma and Hanna 1999; Moser 2009). The mixture called as feed phase was passed through the membrane bioreactor (MBR) continuously by a pump for

Table 2 Composition of casting solutions

\begin{tabular}{|c|c|c|c|}
\hline Sample code & $\begin{array}{l}\text { \% Polymer } \\
(w / w)\end{array}$ & $\begin{array}{l}\text { \% DBP } \\
(w / w)\end{array}$ & $\begin{array}{l}\% \text { PEG } \\
(w / w)\end{array}$ \\
\hline PES-10 & 10 & 0 & 0 \\
\hline $\mathrm{PESNH}_{2}-10$ D2 P5 & 10 & 2 & 5 \\
\hline $\mathrm{PESNH}_{2}-10$ D5 P8 & 10 & 5 & 8 \\
\hline $\mathrm{PESNH}_{2}-10$ D8 P5 & 10 & 8 & 5 \\
\hline $\mathrm{PESNH}_{2}-10$ D5 P10 & 10 & 5 & 10 \\
\hline $\mathrm{PESNH}_{2}-10$ D10 P5 & 10 & 10 & 5 \\
\hline
\end{tabular}

$D$ DBP, $P$ PEG. The number in the code sample represents concentration of the components in weight percent $(w / w)$

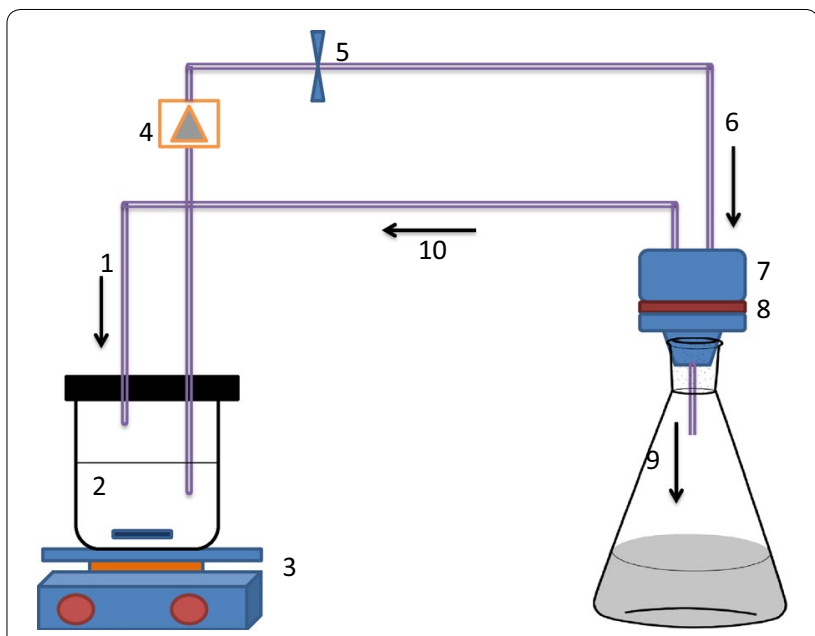

Fig. 1 Schematic diagram of MBR. 1 Entry of retentate phase; 2 Mixture of triglyceride and alcohol as feed phase; 3 Hot plate included magnetic stirrer; 4 Pump; 5 Valve; 6 Entry of feed phase; 7 Membrane cell; 8 Membrane reactor; 9 Permeate phase; 10 Retentate phase will go back to the container

$24 \mathrm{~h}$ at $50{ }^{\circ} \mathrm{C}$. MBR separated permeate phase and retentate phase based on the physical and chemical properties of the membrane. All of the products were collected and tested by liquid chromatography-mass spectrometer (LC-MS) which is completed by a binary pump. The tools were connected with mass spectrometer Q-TOF including electrospray ionization (ESI). Full-scan modus from 100$1200 \mathrm{Da}(\mathrm{m} / \mathrm{z})$ were performed at $140{ }^{\circ} \mathrm{C}$. The Supelco column $5 \mu \mathrm{C} 18,250 \times 2 \mathrm{~mm}$ id was used in the measurement. Solvent A which contains the water with $0.3 \%$ of acetic acid and solvent $B$ which contains methanol and $0.3 \%$ of acetic acid were used in this analysis. The total of flow rate during the measurement was $0.5 \mathrm{~mL} / \mathrm{min}$. The sample was injected with $20 \mu \mathrm{L}$ of volume and the flow rate $1 \mathrm{~mL} / \mathrm{min}$. The determination of biodiesel quality was investigated by freezing point, cloud point, iodine value, kinematic viscosity, density, and the flame test.

\section{The synthesis of the cross-linked membrane bioreactors using glutaraldehyde as cross-linker}

An aminated PES membrane with certain composition of DBP and PEG (PESNH $2-10$ D8 P5) in a circle shape with diameter of $2 \mathrm{~cm}$ and the thickness of $1.045-0.05 \mathrm{~mm}$ was mixed with $4 \mathrm{~mL}$ of glutaraldehyde solution $10 \%$ $(w / w)$ in a PBS buffer (pH 7). The selection was performed based on the enzyme loading value in the previous investigation (the amount of lipase immobilized onto $\mathrm{PESNH}_{2}-10 \mathrm{D} 8 \mathrm{P} 5$ was the largest) (Handayani et al. 2012). After incubation in a rotary shaker at room temperature for $3 \mathrm{~h}$, the membrane was dried and applied as 
solid support for lipase. For the next step, the obtained membrane was called as cross-linked membrane. Lipase solution $(2 \mathrm{mg} / \mathrm{mL})$ in a PBS buffer $(\mathrm{pH} 7)$ was mixed with the cross-linked membrane in a rotary shaker at $30{ }^{\circ} \mathrm{C}(200 \mathrm{rpm})$ for $24 \mathrm{~h}$. Separation of the immobilized lipase and the supernatant was performed by decantation. The cross-linked membrane bioreactor was washed by a PBS buffer solution ( $\mathrm{pH} 7)$ and distilled water until no further protein was detected on the solution. Supernatant and the washing solution were kept for determination of the enzyme loading, while the cross-linked membrane bioreactor was dried on a vacuum oven at room temperature for $24 \mathrm{~h}$. The enzyme loading was obtained by Lowry method (Lowry et al. 1951).

\section{The determination of iodine value}

An amount of $0.05 \mathrm{~g}$ of biodiesel was heated and mixed with $1.5 \mathrm{~mL}$ of $n$-hexane. $2.5 \mathrm{~mL}$ of Wijs reagent was added to the mixture and then kept in a closed container at room temperature for $30 \mathrm{~min}$. The mixture was added by $15 \%(w / w)$ of $\mathrm{KI}$ and dissolved by $10 \mathrm{~mL}$ of distilled water. The solution was then titrated by sodium thiosulfate $\left(\mathrm{Na}_{2} \mathrm{~S}_{2} \mathrm{O}_{3}\right) 0.02 \mathrm{~N}$ with amylum as an indicator until the blue color disappeared. The blank solution (without biodiesel) was also titrated by $\mathrm{Na}_{2} \mathrm{~S}_{2} \mathrm{O}_{3}$ with the same procedure. The iodine value was calculated as follows:

$$
\text { Iodine value }(\%)=\frac{12.69(B-C) N}{W}
$$

where $B$ was the volume of $\mathrm{Na}_{2} \mathrm{~S}_{2} \mathrm{O}_{3}$ in a blank titration, $C$ was the volume of $\mathrm{Na}_{2} \mathrm{~S}_{2} \mathrm{O}_{3}$ in a biodiesel titration, $N$ represented the normality of $\mathrm{Na}_{2} \mathrm{~S}_{2} \mathrm{O}_{3}$, and $W$ was the weight of biodiesel used in the reaction.

\section{The density test of biodiesel}

The density test was carried out according to the standardized procedure from ASTM D1298. Pycnometer was washed by ethanol and dried in the oven. The weight of empty pycnometer was measured and filled with distilled water $\left(40{ }^{\circ} \mathrm{C}\right)$ until the capillary hole in the stopper was filled with water. The pycnometer was then kept at $40{ }^{\circ} \mathrm{C}$ for $30 \mathrm{~min}$ and the weight was measured. Biodiesel was poured into the dried pycnometer and incubated at $40^{\circ} \mathrm{C}$ for $30 \mathrm{~min}$ and balanced. The density of biodiesel was determined by the equation below:

$$
\text { Density }\left(\mathrm{kg} / \mathrm{m}^{3}\right)=\frac{F\left(m_{2}-m_{0}\right)}{m_{1}-m_{0}}
$$

where $F$ represented the density of distilled water in the vacuum condition, $m_{0}$ was the weight of empty pycnometer, $m_{1}$ was the weight of pycnometer that filled by distilled water, and $m_{2}$ was the weight of pycnometer that filled by biodiesel.

\section{The kinematic viscosity measurement of biodiesel}

The kinematic viscosity test was carried out by following the ASTM D445 procedure. An amount of $10 \mathrm{~mL}$ of distilled water was incubated at $40^{\circ} \mathrm{C}$ for $30 \mathrm{~min}$ and poured into an Ostwald viscometer. The flow time of water as a blank was investigated. Meanwhile, the flow time of biodiesel was measured after incubation at $40{ }^{\circ} \mathrm{C}$ for $30 \mathrm{~min}$. The viscosity of biodiesel was determined from the calculation using this equation:

$$
\text { Kinematic viscosity }\left(\mathrm{mm}^{2} / \mathrm{s}\right)=\frac{d_{2} x t_{2}}{d_{1} x t_{2}}
$$

where $d_{1}$ was the density of distilled water, $d_{2}$ was the density of biodiesel, $t_{1}$ was the flow time of distilled water as blank, and $t_{2}$ was the flow time of biodiesel.

\section{Result and discussions}

\section{PES-NH $\mathrm{N}_{2}$ membrane as a solid support for enzymes}

The membrane was prepared by an inversion phase technique using distilled water as the coagulation bath. Dibutyl phthalate (DBP) and polyethylene glycol (PEG) were presented in the casting solution as a plasticizer and a pore-size controller, respectively. The trapped gas in the casting solution was removed by an ultrasonic bath to gain the homogeneous solution. With a proper immersion process, an effective exchange between a solvent and non-solvent phase will be produced, hence a good performance membrane will be released from the glass. One of the important things in the membrane production was the choice of solvent for polymer. It should have a high dissolving strength and a great volatility to produce an optimum interaction between polymer and the solvent (Guan et al. 2006).

The successful attachment of the enzyme to the membrane depends on the active groups existing on the membrane and the pore-size parameter. If the pores of the membrane have a small size, it would cause the limitation in the diffusion capability and rearrangement of enzymes structure which resulted in the reduction of enzyme activity. On the contrary, the very large pore sizes would minimize the interaction between the enzymes and their solid support which resulted in an enzyme leaching out phenomenon. The surface area and the membrane's porosity parameter were determined by Brunauer, Emmet, and Teller (BET) method. The detected BET surface areas for each membrane (PES-10, $\mathrm{PESNH}_{2}-10$ D2 P5 before immobilization, and $\mathrm{PESNH}_{2}-10$ D2 P5 after immobilization) were as 3, 12, 
and $43 \mathrm{~m}^{2} / \mathrm{g}$, respectively. The membranes were selected to check the effect of additives and amination process toward the membrane's properties. Moreover, according to the previous report, $\mathrm{PESNH}_{2}-10 \mathrm{D} 2 \mathrm{P} 5$ has a high enzyme loading value (Handayani et al. 2012). Based on the results, it can be inferred that the amount of monolayer adsorbed gas onto $\mathrm{PESNH}_{2}-10$ D2 P5 membrane after immobilization was the largest. Therefore, by immobilization of enzyme, the ability of adsorbent to capture the adsorbate and form a chemical interaction becomes greater. Porosity parameter of PES and $\mathrm{PESNH}_{2}$ -10 D2 P5 membranes before immobilization was difficult to be detected due to the small value of BET surface area. The total pore volume of $\mathrm{PESNH}_{2}-10$ D2 P5 after immobilization was $0.12 \mathrm{~cm}^{3} / \mathrm{g}$ and the diameter was in a range of $3-20 \mathrm{~nm}$. The range of pores diameter indicates that the membrane was categorized as mesoporous membrane.

The immobilization of M. miehei lipase onto a membrane was performed in a PBS buffer $(\mathrm{pH} 7)$ at $30^{\circ} \mathrm{C}$ for $24 \mathrm{~h}$. The type of enzyme interaction with its solid support could be investigated by SEM characterization. SEM image of immobilized lipase onto $\mathrm{PESNH}_{2}-10 \mathrm{D} 2$ P5 membrane is shown in Fig. 2. Based on the image, the lipase seen in Fig. 2b is not present in Fig. 2a. The lipase detected on the image seems to be not covalently attached, but only physically interacted with the solid support.

Elemental analysis by SEM-EDX was carried out to investigate the percentage of elements that are present on the membranes. As can be seen from Table 3, percentage of nitrogen $(\mathrm{N})$ and oxygen $(\mathrm{O})$ in $\mathrm{PESNH}_{2}-10 \mathrm{D} 2 \mathrm{P} 5$ membrane after immobilization was greater than that of the membrane before immobilization. According to the
Table 3 The percentage of elements contained in the membrane before and after immobilization

\begin{tabular}{llll}
\hline Sample code & $\begin{array}{l}\text { Amount } \\
\text { of } \mathbf{C}(\%)\end{array}$ & $\begin{array}{l}\text { Amount } \\
\text { of } \mathbf{O}(\%)\end{array}$ & $\begin{array}{l}\text { Amount } \\
\text { of } \mathbf{N}(\%)\end{array}$ \\
\hline PESNH 2 -10 D2 P5 & 43.46 & 15.85 & 17.35 \\
PESNH 2 -10 D2 P5 (immobilized) & 42.93 & 18.10 & 23.11 \\
\hline
\end{tabular}

result, it can be shown that Mucor miehei lipase was successfully interacted with the membrane and contributed to a percentage of $\mathrm{N}$ and $\mathrm{O}$. The increasing amount of $\mathrm{N}$ and $\mathrm{O}$ was obtained from amide $\left(-\mathrm{CO}_{2}-\mathrm{NH}-\right)$ bonds and primary amine $\left(-\mathrm{NH}_{2}\right)$ or carboxyl groups $(-\mathrm{COOH})$ located on the repeating unit and the terminal groups of protein.

The interaction of lipase by physical adsorption onto the solid support is the most widely used method in enzymes immobilization. This adsorption type offers several advantages such as simplest operational procedure, specificity of the substrate and maintainability of the enzymes activity, low cost operation, and ease of solid support regeneration. However, immobilization of enzyme by physical adsorption is also known to have a main limitation which is the enzyme immobilized onto the support surfaces will leach out for several cases (Balcao et al. 1996). Therefore, an optimization of functional groups was greatly needed in the system to produce a high performance of membrane reactor.

\section{Immobilized lipase as bioreactor}

The immobilization of enzyme was carried out for $24 \mathrm{~h}$ to produce the enzyme that is successfully attached onto the membrane surface or pores in a proper condition. The enzyme loading is described in Table 4.
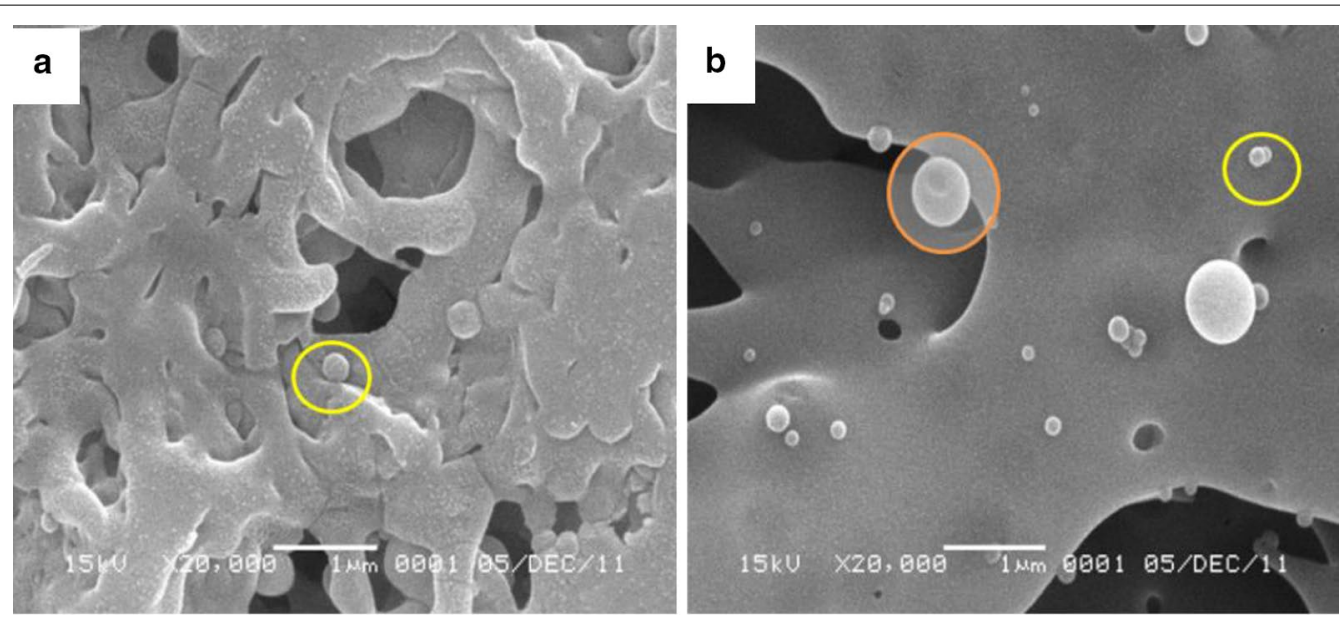

Fig. 2 The SEM images of PESNH2-10 D2 P5 at 20,000 times magnification. a Without immobilized lipase; and $\mathbf{b}$ with the presence of immobilized lipase. The yellow circle indicates a DBP particle, while the orange circle indicated as the lipase immobilized onto the membrane 
Table 4 The enzyme loading of lipase immobilized onto membranes with various concentrations of additives

\begin{tabular}{|c|c|}
\hline Sample code & Enzyme loading $\left(\mu \mathrm{g} / \mathrm{cm}^{2}\right)$ \\
\hline Commercial PES filtration membrane & 185.56 \\
\hline PES 10 & 195.21 \\
\hline $\mathrm{PESNH}_{2}-10$ D5 P8 & 199.96 \\
\hline $\mathrm{PESNH}_{2}-10 \mathrm{D} 8 \mathrm{P} 5$ & 187.60 \\
\hline $\mathrm{PESNH}_{2}-10$ D5 P10 & 194.25 \\
\hline $\mathrm{PESNH}_{2}-10 \mathrm{D} 10 \mathrm{P5}$ & 192.89 \\
\hline
\end{tabular}

A commercial PES filtration membrane was used with a pore size of $0.65 \mu \mathrm{m}$ and a diameter of $47 \mathrm{~mm}$

As shown in Table 4, enzyme loading values of synthesized membrane were greater than that of commercial filtration membrane. This fact indicates that the synthesized PES with a lower molecular weight will generate a difference of morphology and distribution of pores in the membranes. A greater molecular weight of polymer will produce a membrane with a more dense structure. It leads the interaction chance between the enzyme and PES obtained by the synthesis was greater than interaction of the enzyme and commercial PES.

The addition of DBP as plasticizer will increase the mechanical strength of the membranes and contribute to the interaction strength between enzyme and the membrane. However, the more DBP added to the mixture will produce denser membrane pores and allow for reducing the formation of interaction between the enzyme and its solid support. To deal with this problem, PEG was added to enlarge the pore size and enable the interaction with the enzyme. Based on the result, the immobilized lipase onto synthesized PES and PES- $\mathrm{NH}_{2}$ membrane is potential to be applied as MBR.

The investigation of enzymes activity was performed by applying the immobilized lipase as a biocatalyst in the biodiesel synthesis. The source of triglyceride used in this transesterification reaction was sunflower oil. The oil was selected on this study based on several factors, such as the plant can be easily grown and harvested in Indonesia, the triglyceride is a good substrate in the biodiesel synthesis due to a high stability of alkyl ester (Akoh et al. 2007), and high level of unsaturated fatty acid leading to an ease of handling (Enferadi et al. 2006).

$\mathrm{PESNH}_{2}-10$ D5 P8 membrane containing immobilized lipase was inserted in the membrane bioreactor (MBR) as shown in Fig. 1. The reactants (triglyceride and butanol) were mixed in the container and then flowed into the MBR. In this case, butanol and fatty acid alkyl ester (FAAE) were miscible at reaction temperature $\left(50{ }^{\circ} \mathrm{C}\right)$. The immiscibility of sunflower oil and butanol is the major problem in the mass transfer for biodiesel synthesis. However, the formation of emulsion during reaction is necessary in biodiesel synthesis using membrane reactor. Therefore, the conversion of triglyceride to form FAAE by esterification reaction is ideally suited to be operated in a membrane reactor.

The process of biodiesel synthesis was continuously performed using a pump to form FAME with a high yield in the permeate phase. After $24 \mathrm{~h}$, the phase was then collected and measured by LC-MS. As shown in Fig. 3, the permeate phase produced from transesterification between sunflower oil and butanol resulted in eight peaks of retention time. C18 was used as a column in the measurement. The type of this stationary phase is a non-polar column that leads to retain a non-polar compound longer than a polar compound in the matrix of C18. A peak was identified as butyl palmitate with a molecular weight of $312 \mathrm{Da}(\mathrm{m} / \mathrm{z})$ that was present at a retention time of $1.88 \mathrm{~min}$ and relative abundance of $4 \%$. The peak appeared with a molecular weight of $351.85 \mathrm{Da}(\mathrm{m} / z)$ because during the measurement, butyl palmitate joined with $\mathrm{K}^{+}$to form a cation. A mixture of methanol and water (90:10) was used in the measurement as a solvent. In this case, $\mathrm{K}^{+}$acted as pseudomolecular ion.

The next butyl ester identified in the chromatogram was butyl linoleate with a molecular weight of $336.98 \mathrm{Da}$ and relative abundance of $6 \%$. This peak appeared in the retention time of $3.17 \mathrm{~min}$. The molecular weight of butyl linoleate is $336 \mathrm{Da}(\mathrm{m} / \mathrm{z})$. Therefore, the FAAE joined with $\mathrm{H}^{+}$as pseudomolecular ion to form the detected cation.

The last peak appeared on the retention time of 4.33 min with molecular weight of $337.06 \mathrm{Da}(\mathrm{m} / z)$. The peak was detected as butyl oleate with molecular weight of $338 \mathrm{Da}(\mathrm{m} / z)$ and $\mathrm{K}^{+}$as pseudomolecular ion. Butyl oleate can be identified in the chromatogram with a very large relative abundance, which is equal to $100 \%$.

The investigation results of components on the permeate phase by LC-MS were in accordance with the compositions of fatty acids residue on the triglyceride. The greatest component in the triglyceride of sunflower oil is residue of oleic acid and followed by residue of linoleic acid. The residue of palmitic acid was lower than two fatty acids that have been mentioned previously. The content of stearic acid residue in the oil is the least resulting in no detection of butyl stearic peak in the chromatogram. 
a

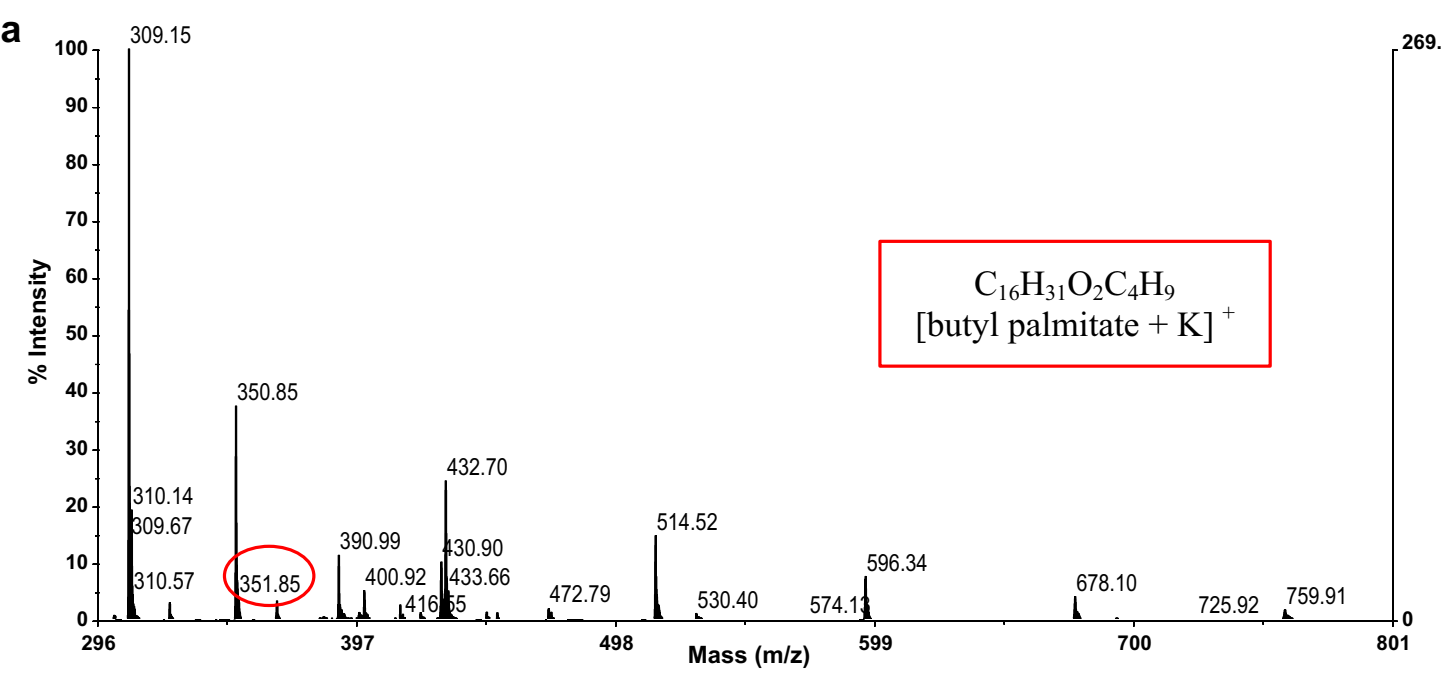

b
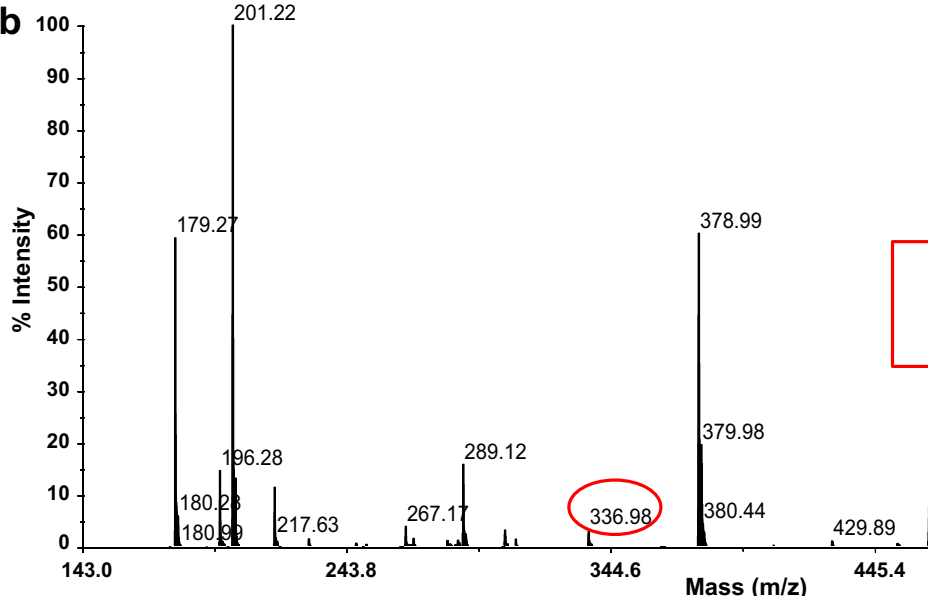

$\mathrm{C}_{18} \mathrm{H}_{31} \mathrm{O}_{2} \mathrm{C}_{4} \mathrm{H}_{9}$

[butyl linoleate $+\mathrm{H}]^{+}$
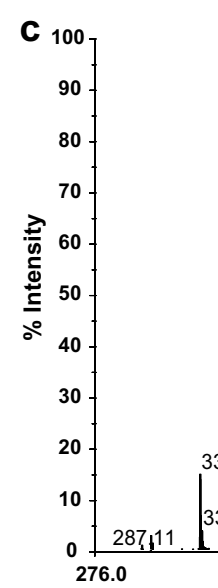

377.06
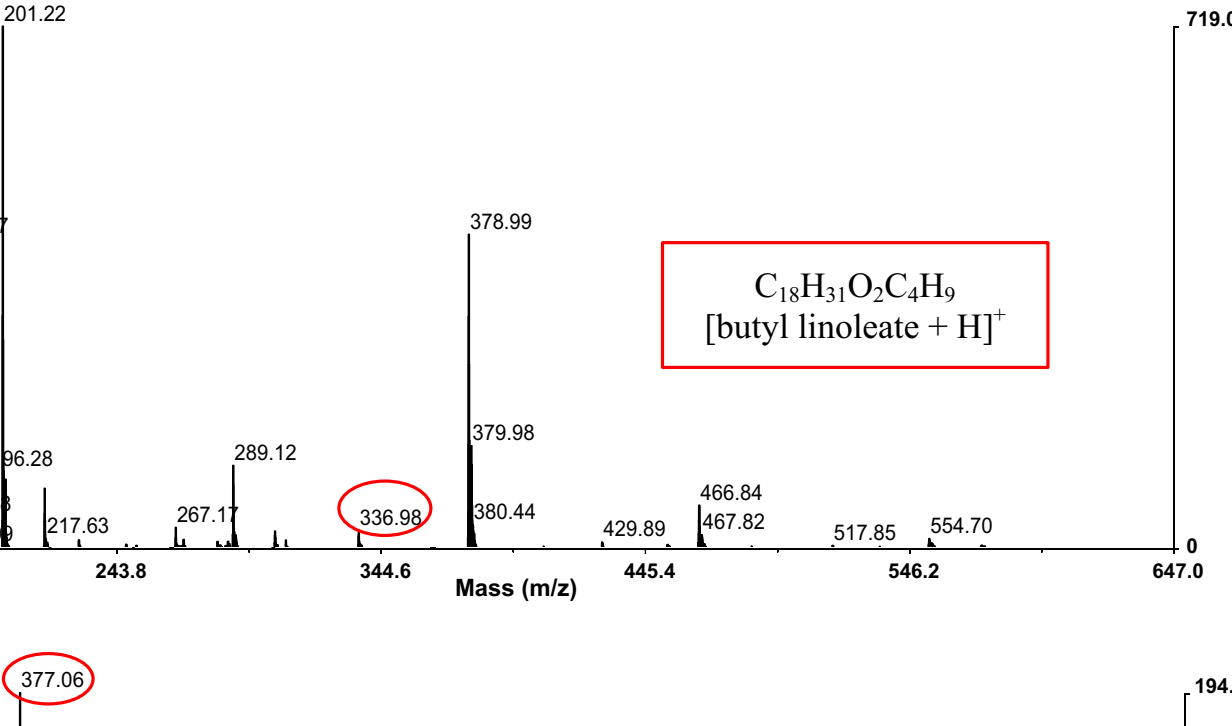

719.0

$\mathrm{C}_{18} \mathrm{H}_{33} \mathrm{O}_{2} \mathrm{C}_{4} \mathrm{H}_{9}$

[butyl oleate $+\mathrm{K}]^{+}$

Fig. 3 LC-MS chromatogram of FAAE produced by transesterification using membrane reactor. $\mathbf{a}$ Retention time of 1.88 min; $\mathbf{b}$ retention time of $3.17 \mathrm{~min}$; and $\mathbf{c}$ retention time of $4.33 \mathrm{~min}$ 
Glycerol is the side product in the transesterification reaction. Based on the chromatogram, there was no peak identified as glycerol. This result was obtained because glycerol was retained on the filter membrane. The hydrophilic interactions between glycerol and the membrane reactor were formed leading to the undetected glycerol on the permeate phase.

\section{The quality determination of the synthesized biodiesel}

Iodine value of synthesized biodiesel was investigated by Wijs method. This value was expressed in grams of iodine for the amount of halogens bonded with $100 \mathrm{~g}$ of biodiesel sample. The iodine value of synthesized biodiesel was calculated from titration volume of sodium thiosulfate solution. Maximum value of iodine value according to the standard is $115 \%$ ( $\mathrm{g} \mathrm{I}_{2} / 100 \mathrm{~g}$ of sample), while the iodine value of FAAE resulted from the transesterification was $35.28 \%$ ( $\mathrm{g} \mathrm{I}_{2} / 100 \mathrm{~g}$ of sample) (ASTM International 2002). This result indicates that the amount of double bonds in the FAAE was matched with the standard.

The flame test was carried out to distinguish the flammable materials from the combustion materials. Liquids with a lower flash point than 37.8 or $60.5^{\circ} \mathrm{C}$ are called as flammable materials, whereas diesel fuel has a varying flash point in a range of $52-96^{\circ} \mathrm{C}$. According to the flame test, the FAAE was successfully burned in the temperature of $68^{\circ} \mathrm{C}$. Therefore, the flash point of synthesized biodiesel was in the range of the diesel fuels flash point specified by ASTM D93 (ASTM International 1997). With a high flash point, the biodiesel is expected to be safe when it is stored.

The cloud point and pour point are the indicators used to measure the performance of biodiesel in a low temperature. According to the result, biowax on the FAAE formed a cloudy appearance in the temperature of $-5^{\circ} \mathrm{C}$ and it was in a range of the cloud point specified by ASTM D2500 (ASTM International 2011). The same tendency was obtained in the pour point test. By the pour point test, the lowest temperature of the materials movement can be identified under the condition of the test. The FAAE synthesized by transesterification reaction had a pour point of $-11^{\circ} \mathrm{C}$ and it was in the range of ASTM D5949 (ASTM International 2014). Based on the density test, the FAAE had a density of $870.32 \mathrm{~kg} / \mathrm{m}^{3}$. This value was matched with the biodiesel specified by ASTM D1298 (ASTM International 1999). Viscosity of biodiesel is an important thing in the fuel engine application because it determines the resistance of a FAAE to shear forces and give an impact toward the operation of fuel injection apparatus. The synthesized FAAE had a kinematic viscosity value of $3.39 \mathrm{Mm}^{2} / \mathrm{s}$ and it was in a range of ASTM D445 (ASTM International 2015). Therefore, it can be concluded that the viscosity and density of synthesized biodiesel met the standard specified by ASTM.

Flame test toward the synthesized biodiesel and the triglyceride was carried out to compare the flame intensity between the product and the reactant. Based on the test, the flame intensity of sunflower oil is the lowest compared to the biodiesel synthesized by free enzyme and an immobilized enzyme as a catalyst. This result indicates that the synthesized biodiesel has a high potential to be applied as biofuel.

\section{The effects of a spacer toward the immobilized enzymes performance}

The use of glutaraldehyde as a cross-linker agent is expected to generate the positive influence toward the immobilized enzymes performance (Migneault et al. 2004). A glutaraldehyde has two aldehyde groups in the structure leading to form a bridge connected the enzyme and the solid support. In a PBS buffer $\mathrm{pH} 7$, one active site of glutaraldehyde reacted with an active group located in the solid support, while another site reacted with primary amine group in the enzyme to form an imine group (-N=C-) (Miletic and Loos 2009). The mechanism of imine formation is illustrated in Fig. 4.

The immobilization of enzymes in the presence and absence of spacer was performed to investigate the effect of glutaraldehyde toward the amount of enzyme that interacted or immobilized onto the solid support. Table 5 shows the enzyme loading value of enzyme immobilized in the presence of spacer compared to the enzyme immobilized without glutaraldehyde.

Based on the enzyme loading tests, after reaction with the spacer, the enzyme loading increased significantly. This result was caused by the increasing of interactions opportunity of the enzyme with the spacer or solid support. An analysis by FTIR spectroscopy was carried out to predict the interaction or bond type produced after the cross-linking reaction. Based on Fig. 5, intensity of primary amine $\left(-\mathrm{NH}_{2}\right)$ peaks $\left(3520 ; 1128\right.$; and $\left.622 \mathrm{~cm}^{-1}\right)$ was decreased after the cross-linker addition. Amide (-CO-NH-) peaks (1230 and $1719 \mathrm{~cm}^{-1}$ ) were present in FTIR spectra of PES-NH $\mathrm{NH}_{2}$ after immobilization, both before and after cross-linking. However, the intensity of amide peaks was decreased after the cross-linker addition. Acrylic acid and acrylamide functional groups (3350, 1685, and $1115.1 \mathrm{~cm}^{-1}$ ) as characteristic peaks of enzyme immobilized onto the membrane appeared in the absorption bands of PES- $\mathrm{NH}_{2}$ after immobilization and immobilized PES- $\mathrm{NH}_{2}$ after cross-linking. The imines 

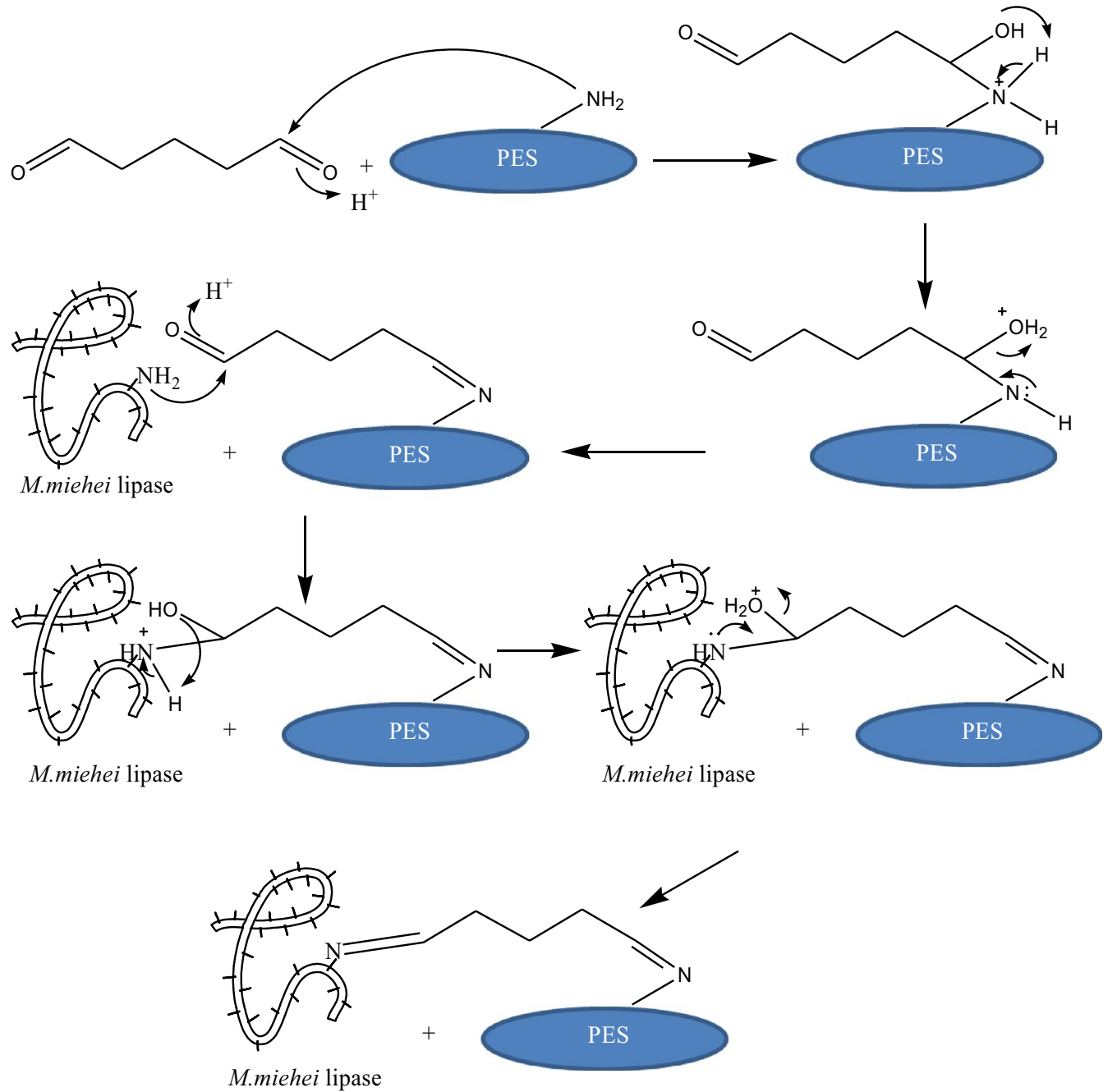

Fig. 4 Mechanism of imine formation

Table 5 The enzyme loading of lipase immobilized onto PES- $\mathrm{NH}_{2}$ in the presence and absence of spacer

\begin{tabular}{ll}
\hline Sample code & Enzyme loading $\left(\boldsymbol{\mu g} / \mathbf{c m}^{\mathbf{2}}\right)$ \\
\hline PESNH $_{2}-10$ D8 P5 & 177.05 \\
PESNH $_{2}-10$ D8 P5 Glut & 911.48 \\
\hline
\end{tabular}

were identified in spectra of PES- $\mathrm{NH}_{2}$ after immobilization and cross-linking reaction in the wave number of $1644 \mathrm{~cm}^{-1}$ which indicates the presence of $-\mathrm{C}=\mathrm{N}$ stretching. $-\mathrm{CH}_{2}$ - rocking in methylene chain of glutaraldehyde $\left(735.5 \mathrm{~cm}^{-1}\right)$ was also identified in the spectra of immobilized enzyme after cross-linking. From the result, it can be concluded that enzyme was successfully attached to PES-NH $\mathrm{N}_{2}$. Moreover, imine group as a covalent bond that resulted from cross-linking was successfully obtained during the reaction.

The transesterification reaction of sunflower oil as triglyceride and methanol was performed to investigate the effects of spacer addition toward an enzyme activity. The characterization of biodiesel produced by transesterification reaction using immobilized enzyme in the presence and absence of spacer is represented in Table 6.

According to the chromatogram, for each of retention time of detected methyl ester, the peak area showed a high value. Therefore, it indicates that the degree of purify of the biodiesel was pretty high. Based on the molecular weight of compound detected in every 


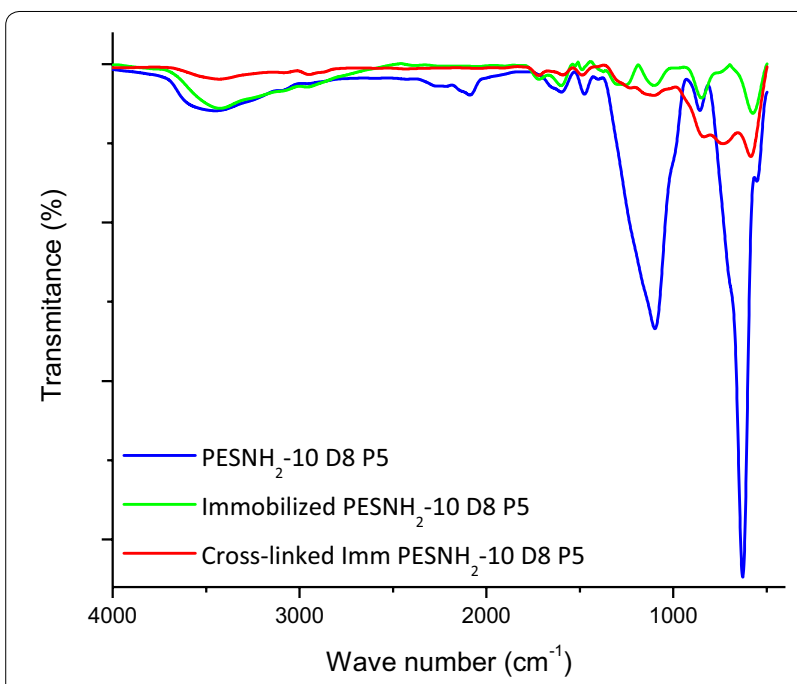

Fig. 5 The FTIR spectra of PES-NH $\mathrm{NH}_{2}$ (blue line); $\mathrm{PES}-\mathrm{NH}_{2}$ after immobilization (green line); and PES-NH $\mathrm{H}_{2}$ after immobilization and cross-linking reaction (red line)

retention time, all of FAAE formed a cation together with $\mathrm{K}^{+}$as a pseudomolecular ion.

The main point of this research was that a synthesis of biodiesel can be performed by using immobilized lipase onto $\mathrm{PESNH}_{2}-10$ D8 P5. The activity of lipase was not decreased significantly compared to the free enzyme as catalysts. The product of transesterification reaction between stearate and methanol by immobilized enzyme as a catalyst produced a higher value of methyl ester abundance than that of the free enzyme. Besides of that, the relative abundance of methyl palmitate obtained from biodiesel conversion using $\mathrm{PESNH}_{2}-10$ D8 P5 with the presence of glutaraldehyde reached $100 \%$. Based on the result, the addition of glutaraldehyde can improve the efficiency of biodiesel conversion. This result was obtained due to the increasing of immobilized enzyme ability to attach the substrate. This method is good to be developed since the immobilized enzyme stability could be increased, the separation process was easier, and a high yield with good quality of biodiesel could be obtained.

\section{Abbreviations}

PES: polyethersulfone; ASTM: American society for testing and materials; FAAE: fatty acid alkyl esters; NMP: N-methyl pyrrolidone; DBP: dibutyl phthalate; PEG: polyethylene glycol; LC-MS: liquid chromatography-mass spectrometry; UV/VIS: ultraviolet/visible; PBS: phosphate buffer solution; MBR: membrane bioreactor; ESI: electrospray ionization; Q-TOF: quadrupole time-of-flight; SEM: scanning electron microscopy; EDX: energy-dispersive X-ray spectroscopy; FTIR: Fourier transform infrared; BET: Brunauer-Emmett-Teller.

\section{Authors' contributions}

$\mathrm{NH}, \mathrm{DW}, \mathrm{B}$, and $\mathrm{MAZ}$ conceived the study. $\mathrm{NH}$ performed the experiments and prepared the manuscript. DW, B, MAZ, SN, and CLR analyzed the data and helped to revise the manuscript. All authors read and approved the final manuscript.

\section{Acknowledgements}

We would like to thank to Indonesian government (Decentralization Research Program by DIKTI-The Directorate General of Higher Education) for their financial support. We are also indebted to Katja Loos, I Made Arcana, and Muhammad Nasir for their kind advices. We greatly appreciate the assistance of Rino R. Mukti for BET analysis, Puspa D. Lotulung, and Teni Ernawati for LC-MS analysis. We would like to thank to Nur Ahmadi for his invaluable help in proofreading this manuscript.

\section{Competing interests}

The authors declare that they have no competing interests.

Received: 24 November 2015 Accepted: 4 April 2016

Published online: 26 April 2016

\section{References}

ASTM International: ASTM D1959 (2002) Standard test method for iodine value of drying oils and fatty acids (withdrawn 2006). ASTM International, West Conshohocken

ASTM International: ASTM D93 (1997) Standard test method for flash point by Pensky-martens closed cup tester. ASTM International, West Conshohocken

ASTM International: ASTM D2500 (2011) Standard test method for cloud point of petroleum products. ASTM International, West Conshohocken

ASTM International: ASTM D5949 (2014) Standard test method for pour point of petroleum products. ASTM International, West Conshohocken

ASTM International: ASTM D1293 (1999) Standard test method for density, relative density (specific gravity), or Api gravity of crude petroleum and liquid petroleum products by hydrometer methodr. ASTM International, West Conshohocken

ASTM International: ASTM D445 (2015) Standard test method for kinematic viscosity of transparent and opaque liquids (and calculation of dynamic viscosity). ASTM International, West Conshohocken

Akoh CC, Chang SW, Lee GC, Shaw JF (2007) Enzymatic approach to biodiesel production. J Agric Food Chem 55:8995-9005

Arica Y, Hasirci VN (1987) Immobilization of glucose-oxidase in poly(2-hydroxyethyl methacrylate) membranes. Biomaterials 8:489-495

Table 6 The result of analysis by LC-MS

\begin{tabular}{|c|c|c|c|c|}
\hline Catalysts & Retention time (minutes) & Peak area & Suspected compound & Relative abundance (\%) \\
\hline \multirow[t]{2}{*}{ Free M. miehei lipase } & 1.73 & 292.89 & Methyl palmitate & 100 \\
\hline & 8.83 & 467.24 & Methyl stearate & 45 \\
\hline \multirow[t]{2}{*}{$\mathrm{PESNH}_{2}-10$ D8 P5 } & 1.83 & 485.78 & Methyl palmitate & 20 \\
\hline & 8.71 & 331.30 & Methyl stearate & 79 \\
\hline \multirow[t]{2}{*}{$\mathrm{PESNH}_{2}-10$ D8 P5 (Glut) } & 1.71 & 481.94 & Methyl palmitate & 100 \\
\hline & 8.66 & 695.00 & Methyl stearate & 58 \\
\hline
\end{tabular}


Balcao VM, Paiva AL, Malcata FX (1996) Bioreactors with immobilized lipases: state of the art. Enzym Microb Technol 18:392-416

Demirbas A (2002) Biodiesel from vegetable oils via transesterification in supercritical methanol. Energy Convers Manag 43:2349-2356

Eldin MSM, Schroen CGPH, Janssen AEM, Mita DG, Tramper J (2000) Immobilization of penicillin $\mathrm{g}$ acylase onto chemically grafted nylon particles. J Mol Catal B Enzym 10:445-451

Enferadi T, Rabiei SZ, Vannozzi GP (2006) Protection of biodiesel based on sunflower oil from oxidative degradation by natural antioxidant. HELIA 29:25-32

Giorno L, Drioli E (2000) Biocatalytic membrane reactors: applications and perspectives. TIBTECH 18:339-349

Guan R, Dai H, Li C, Liu J, Xu J (2006) Effect of casting solvent on the morphology and performance of sulfonated polyethersulfone membranes. Membr Sci 277:148-156

Handayani N, Buchari, Wahyuningrum D (2010) Sintesis dan karakterisasi poli(eter-sulfon) dan poli(eter-sulfon) ternitrasi sebagai material membran untuk imobilisasi lipase. Junal Kimia Indonesia 5(1):7-16

Handayani N, Loos K, Wahyuningrum D, Buchari, Zulfikar MA (2012) Immobilization of mucor miehei lipase onto macroporous aminated polyethersulfone membrane for enzymatic reactions. Membranes 2:198-213

Handayani N, Miletic N, Loos K, Achmad S, Wahyuningrum D (2011) Properties of immobilized candida antarctica lipase $b$ on highly macroporous copolymer. Sains Malays 40:965-972

Hilal N, Kochkodan V, Nigmatullin R, Goncharuk V, Al-Khatib L (2006) Lipaseimmobilized biocatalytic membranes for enzymatic esterification: comparison of various approaches to membrane preparation. J Membr Sci 268:198-207
Keitoku F, Kakimoto MA, Imai Y (1994) Synthesis and properties of aromatic poly(ether sulfone)s and poly (ether ketone)s based on methyl-substituted biphenyl-4,4'-diols. J Polym Sci Part A Polym Chem 32:317-322

Kobayashi J, Mori Y, Kobayashi S (2006) Novel immobilization method of enzymes using a hydrophilic polymer. Chem Commun 40:4227-4229

Lowry OH, Rosebrough NJ, Faar AL, Randall RJJ (1951) Protein measurement with the folin phenol reagent. J Biol Chem 193:265-275

Ma F, Hanna MA (1999) Biodiesel production: a review. Bioresour Technol 70:1-15

Migneault I, Dartiguenave C, Bertrand MJ, Waldron KC (2004) Glutaraldehyde: Behavior in aqueous solution, reaction with proteins, and application to enzyme crosslinking. BioTechniques 5:790-802

Miletic N, Loos K (2009) Over-stabilization of chemically modified and crosslinked candida antarctica lipase $b$ using various epoxides and diepoxides. Aust J Chem 62:799-805

Miletic N, Vukovic Z, Nastasovic A, Loos K (2009) Macroporous poly(glycidyl methacrylate-co-ethylene glycol dimethacrylate) resins - versatile immobilization supports for biocatalysts. J Mol Catal B Enzym 56:196-201

Moser BR (2009) Biodiesel production, properties, and feedstocks. Cell DevBiol Plant 45:229-266

Nelson LA, Foglia TA, Marmer WN (1996) Lipase-catalyzed production of biodiesel. JAOCS 73(8):1191-1195

Soares CMF, Santana MHA, Zanin GM, Castro HFD (2003) Covalent coupling method for lipase immobilization on controlled pore silica in the presence of nonenzymatic proteins. Biotechnol Prog 19:803-807

Tan T, Lu J, Nie K, Deng L, Wang F (2010) Biodiesel production with immobized lipase: a review. Biotechnol Adv 28:628-634

\section{Submit your manuscript to a SpringerOpen ${ }^{\circ}$ journal and benefit from:}

- Convenient online submission

- Rigorous peer review

- Immediate publication on acceptance

- Open access: articles freely available online

- High visibility within the field

- Retaining the copyright to your article

Submit your next manuscript at $\boldsymbol{\nabla}$ springeropen.com 